\title{
Pre-trial 'Protective Measures for the Purpose of Forfeiture' at the International Criminal Court: Safeguarding and balancing competing rights and interests
}

\author{
Daley J. Birkett ${ }^{\star}$ (i) \\ University of Amsterdam, Nieuwe Achtergracht 166, 1018WV Amsterdam, The Netherlands; University of Kiel, Westring \\ 400, 24118 Kiel, Germany \\ Email: d.j.birkett@uva.nl
}

\begin{abstract}
The International Criminal Court is empowered by its constituent instrument to request its states parties to identify, trace, freeze, and seize assets 'after a warrant of arrest or a summons has been issued ... having due regard to the strength of the evidence and the rights of the parties concerned'. This article critically examines the approach adopted by the Court to requesting such protective measures at the pre-trial phase, reflecting on how the rights and interests of the primary stakeholders implicated by this process: (i) accused persons, (ii) the Prosecutor, (iii) victims, and (iv) bona fide third parties, are safeguarded and balanced.
\end{abstract}

Keywords: assets; forfeiture; human rights; International Criminal Court; protective measures

\section{Introduction}

Under Article 93(1)(k) of the Rome Statute, the International Criminal Court (ICC or Court) is able to request its states parties to identify, trace, freeze, and seize assets in relation to investigations or prosecutions'. 'Such measures can be requested by the pre-trial chamber, under Article 57(3)(e) of the ICC Statute, 'after a warrant of arrest or a summons has been issued ... having due regard to the strength of the evidence and the rights of the parties concerned'. ${ }^{2}$ This article explores the rights and interests of the four principal stakeholders in this process: (i) accused persons, (ii) the Prosecutor, (iii) victims, and (iv) bona fide third parties, and reflects on how they are safeguarded and balanced.

If forfeited after conviction, frozen and seized assets can be used to fund reparations to the victims of the crimes at issue. This function is confirmed by Article 57(3)(e) of the Rome Statute, which provides that such measures can be requested in particular for the ultimate benefit of victims'. ${ }^{3}$ However, asset freezing measures at the pre-trial phase of ICC proceedings are not

${ }^{*}$ This article is based on a paper given by the author at the $6^{\text {th }}$ Biennial Conference of the Asian Society of International Law, Junior Scholars' Workshop, held at Yonsei University in Seoul, Republic of Korea, on 24-25 August 2017. The author is grateful to Upendra Acharya, Buhm-Suk Baek and Ethan Hee-Seok Shin for critical discussion of the paper. The author also wishes to thank Nina Jørgensen, Gregory Gordon, Göran Sluiter, Denis Abels and the two anonymous peer reviewers for their feedback on earlier drafts of this article.

${ }^{1} 2002$ Rome Statute of the International Criminal Court, 2187 UNTS 90, Art. 93(1)(k).

${ }^{2}$ Ibid., at Art. 57(3)(e).

${ }^{3}$ Ibid.

(C) The Author(s) 2019. This is an Open Access article, distributed under the terms of the Creative Commons Attribution licence (http:// creativecommons.org/licenses/by/4.0/), which permits unrestricted re-use, distribution, and reproduction in any medium, provided the original work is properly cited. 
only a vital tool to enable the enforcement of future reparation awards, but may also be a crucial element of prosecutorial strategy. The Prosecutor is therefore a second concerned party within the meaning of the Rome Statute. Third, as accused persons are the direct objects of asset freezing measures requested by pre-trial chambers, their rights are clearly at stake. A fourth category of stakeholders whose rights may be affected is third parties, whether persons or entities, who own the concerned asset(s) and/or who have a right in property in the hands of the accused. This article critically examines the practice of the ICC with respect to requesting pre-trial protective measures.

Reflecting on the law and practice of the ICC, the article contends that such measures are ultimately essential to enable the court to meet the interests of victims and to fulfil its restorative mandate. Moreover, even if the ICC were to abandon its restorative aims, such measures are useful prosecutorial tools. After demonstrating that the Rome Statute system introduces a series of checks and balances aimed at guaranteeing the rights and interests of the concerned parties during the pre-trial protective measures process, the article concludes that the ICC's approach to date has been progressive and, by and large, consistent. Before turning to the Rome Statute, however, the article will first briefly discuss the employment of such measures at other international(ized) criminal tribunals (ICTs) with a view to distilling (some of) the reasons for their utility thereto in fulfilling their respective mandates.

\section{Protective measures at international(ized) criminal tribunals}

The power to request pre-trial protective measures for the purpose of forfeiture can also be seen in the constituent instruments and relevant rules of procedure and evidence of a series of ICTs established before and after the entry into force of the Rome Statute. These include Control Council Law No. 10, ${ }^{4}$ the Rules of Procedure and Evidence of the Special Court for Sierra Leone (SCSL), ${ }^{5}$ the Senegalese Code of Criminal Procedure applicable before the Extraordinary African Chambers (EAC), ${ }^{6}$ the Rules of Procedure and Evidence of the Special Tribunal for Lebanon (STL), ${ }^{7}$ and the Law on Specialist Chambers and Specialist Prosecutor's Office establishing the Kosovo Specialist Chambers (SPO and KSC). ${ }^{8}$

\footnotetext{
${ }^{4}$ Control Council Law No. 10, 3 Official Gazette Control Council for Germany 50-5, at art. III(1): 'Each occupying authority, within its Zone of Occupation, (a) shall have the right to cause persons within such Zone suspected of having committed a crime ... to be arrested and shall take under control the property, real and personal, owned or controlled by the said persons, pending decisions as to its eventual disposition.'

${ }^{5}$ Special Court for Sierra Leone, Rules of Procedure and Evidence, as amended on 31 May 2012 (SCSL RPE), at Rule 104: '(A) After a judgement of conviction ... the Trial Chamber, at the request of the Prosecutor or at its own initiative, may hold a special hearing to determine the matter of property forfeiture, including the proceeds thereof, and may in the meantime order such provisional measures for the preservation and protection of the property or proceeds as it considers appropriate. (B) The determination may extend to such property or proceeds, even in the hands of third parties not otherwise connected with the crime, for which the convicted person has been found guilty.' For discussion of its application see Prosecutor v. Norman and others, Decision on Inter Partes Motion by Prosecution to Freeze the Account of the Accused Sam Hinga Norman at Union Trust Bank (Sl) Limited or at Any Other Bank in Sierra Leone, SCSL-04-14-PT, T.Ch., 19 April 2004.

${ }^{6}$ Senegalese Code of Criminal Procedure, Art. 87 bis: 'Lorsqu'il est saisi d'un dossier d'information, le juge d'instruction peut d'office ou sur demande de la partie civile ou du ministère public, ordonner des mesures conservatoires sur les biens de l'inculpé.' For its application, see Le Procureur Général v. Hissein Habré, Order for provisional measures, EAC Investigative Chamber, 29 October 2013. See also Le Procureur Général v. Hissein Habré, Judgment, EAC A.Ch., 27 April 2017, at para. 296.

${ }^{7}$ Special Tribunal for Lebanon, Rules of Procedure and Evidence as amended on 3 April 2017, STL-BD-2009-01-Rev.8, at Rule 82 (C): 'Upon request of the Prosecutor or the Registrar, or proprio motu after having heard the Defence, the Pre-Trial Judge or the Trial Chamber may request a State or States to adopt provisional measures to freeze the assets of the accused, without prejudice to the rights of third parties.'

${ }^{8} 2015$ Law on Specialist Chambers and Specialist Prosecutor's Office No.05/L-053, Official Gazette of the Republic of Kosovo, No. 27, 31 August 2015, at Art. 39, para. 11: 'The Pre-Trial Judge may, where necessary, provide for ... the preservation of assets which may be subject to a forfeiture ... including temporary freezing orders, temporary confiscation orders or other temporary measures.'
} 
The ad hoc International Criminal Tribunals for the former Yugoslavia (ICTY) and for Rwanda (ICTR), established by the UN Security Council following the end of the Cold War in response to the mass crimes committed in the former Yugoslavia ${ }^{9}$ and Rwanda, ${ }^{10}$ respectively, were also allowed to order protective measures at the arrest warrant stage. Rule 61(D) of the Rules of Procedure and Evidence of the ICTY and ICTR empowered Trial Chambers to order asset freezing measures, similar to the powers available to the military tribunals established pursuant to Control Council Law No. $10 .^{11}$

The Rule 61(D) procedure was first implicated in 1999 in response to an application by the ICTY Prosecutor to freeze assets belonging to former Yugoslav President, Slobodan Milošević, and his co-accused, Milan Milutinović, Nikola Šainovic, Dragoljub Ojdanić, and Vlajko Stojiljković. ${ }^{12}$ Responding to the Prosecutor's application for the freezing of assets, ${ }^{13}$ Judge David Hunt ordered all UN member states to ascertain 'whether the accused (or any of them) have assets located in their territory and, if so, adopt provisional measures to freeze such assets, without prejudice to the rights of third parties, until the accused are taken into custody'. ${ }^{14}$

In discussing the merits of the Prosecutor's application, Judge Hunt explicitly noted the primary function of pre-trial asset freezing procedures as 'preventing an accused who is still at large from using those assets to evade arrest and from taking steps to disguise his assets or putting them beyond the reach of the Tribunal. ${ }^{15}$ Judge Hunt also accepted the Prosecutor's submission that a second function of freezing the assets of accused persons at ICTs is, to facilitate the 'restitution of property or payment from its proceeds'. ${ }^{16}$ In the month after this decision was issued by the ICTY, Switzerland took measures to freeze assets on its territory belonging to Milošević and his four co-accused. ${ }^{17}$

Based on the decisions made publicly available by the ICTs empowered to request the imposition of pre-trial protective measures, it would appear that such requests are rare. However, it is notable that the power to request such measures has continually been made available to a series of ICTs established before and after the entry into force of the Rome Statute in 2002. The following section will discuss the legal framework at the disposal of the ICC under its constituent instrument and Rules of Procedure and Evidence (RPE).

\section{Protective measures at the ICC}

Article 57(3) of the Rome Statute provides, in relevant part, as follows:

In addition to its other functions under this Statute, the Pre-Trial Chamber may: ...

\footnotetext{
${ }^{9} \mathrm{UN}$ Doc. S/RES/827 (1993).

${ }^{10}$ UN Doc. S/RES/955 (1994).

${ }^{11}$ ICTY, Rules of Procedure and Evidence, as amended on 8 July 2015, UN Doc. IT/32/Rev. 50, at Rule 61; ICTR, Rules of Procedure and Evidence, as amended on 13 May 2015, UN Doc. ITR/3/Rev.23, at Rule 61(D) ('... Upon request by the Prosecutor or proprio motu, after having heard the Prosecutor, the Trial Chamber may order a State or States to adopt provisional measures to freeze the assets of the accused, without prejudice to the rights of third parties').

${ }^{12}$ Prosecutor v. Milošević and others, Decision on Review of Indictment and Application for Consequential Orders, Case No. IT-99-37-I, T.Ch., 24 May 1999 (Milošević and others Decision).

${ }^{13}$ Though the Prosecutor's application was initially based upon Rule 54 of the ICTY RPE, Judge Hunt ruled that relief under Rules 54 and 61(D) may be given 'for the same reasons'. Milošević and others Decision, supra note 12, at 28. Rule 54 provides as follows: 'At the request of either party or proprio motu, a Judge or a Trial Chamber may issue such orders, summonses, subpoenas, warrants and transfer orders as may be necessary for the purposes of an investigation or for the preparation or conduct of the trial.'

${ }^{14}$ Milošević and others Decision, supra note 12 , at para. 38.

${ }^{15}$ Ibid., at 27. See also C. McCarthy, Reparations and Victim Support in the International Criminal Court (2012), at 47; R. Young, 'Fines and Forfeiture in International Criminal Justice', in R. Mulgew and D. Abels (eds.), Research Handbook on the International Penal System (2016), 102, at 104.

${ }^{16}$ Milošević and others case, supra note 12, at para. 27.

${ }^{17}$ See Décision de l'Office fédéral de la police dans l'affaire Milosevic Slobodan et autres, 23 June 1999, available at www. admin.ch/opc/fr/federal-gazette/1999/4796.pdf. Frozen assets belonging to Milošević were unfrozen following his death in March 2006 (see McCarthy, supra note 15, at 47).
} 
(e) Where a warrant of arrest or a summons has been issued under article 58, and having due regard to the strength of the evidence and the rights of the parties concerned, as provided for in this Statute and the Rules of Procedure and Evidence, seek the cooperation of States pursuant to article 93, paragraph $1(\mathrm{k})$, to take protective measures for the purpose of forfeiture, in particular for the ultimate benefit of victims. ${ }^{18}$

According to Article 93(1) of the Rome Statute, ICC states parties are under an explicit obligation to comply with requests from the court to provide ... assistance in relation to investigations or prosecutions ${ }^{19}$ pursuant to their national laws. Subparagraph $(\mathrm{k})$ of the same provision provides that such assistance extends to ' $\mathrm{t}]$ he identification, tracing and freezing or seizure of proceeds, property and assets and instrumentalities of crimes for the purpose of eventual forfeiture, without prejudice to the rights of bona fide third parties'. ${ }^{20}$

As to the 'rights of the parties concerned', the ICC legal framework provides for a series of safeguards, substantive and procedural, enabling it to strike a fair balance between the interests of the four primary stakeholders implicated by the pre-trial protective measures process. Here, an analogy can be drawn between the use of such measures at the ICC and asset freezing by the UN Security Council under Chapter VII of the UN Charter. Writing about the need for checks and balances with respect to the latter, Bantekas expresses the following view:

Freezing and confiscation aim to deter the use of assets for the perpetration of criminal offences by the owner or other persons. Therefore, they are not forms of punishment, especially given that freezing and confiscation can take place prior to the suspect's criminal trial. It is consequently imperative for ... individual suspects ... including their representatives and family members, to have access to procedures that allow them to contest and challenge both the listing and the administrative measures of freezing and confiscation, even if such procedures need not be as high as those enjoyed in a criminal proceeding. ${ }^{21}$

As Bantekas suggests, because (international) criminal proceedings do not share the same 'administrative' character as asset freezing and confiscation under the auspices of the UN Security Council, the procedural safeguards available with respect to the former ought to be stronger. Such safeguards can be found in both the Rome Statute and the ICC RPE.

\subsection{The evidentiary threshold}

One such safeguard can be found in the text of Article 57(3)(e) of the Rome Statute itself. Guariglia and Hochmayr observe that the initial proposed formulations of this provision, which they note was added towards the end of the United Nations Diplomatic Conference of Plenipotentiaries on the Establishment of an International Criminal Court, ${ }^{22}$ 'included no clear evidentiary threshold' for the issuance of pre-trial protective measures. ${ }^{23}$ Such a state of affairs having 'caused discomfort to many delegations', ${ }^{24}$ however, the final text agreed in Rome expressly requires that 'a warrant of arrest or a summons has been issued' under Article 58 of the Rome Statute before the Pre-Trial Chamber can request states to take such measures. The evidentiary threshold required under Article 57(3)(e) of the Rome Statute must therefore be 'reasonable grounds to believe that the

\footnotetext{
${ }^{18}$ Rome Statute, supra note 1 , at Art. 57(3).

${ }^{19}$ Ibid., at Art. 93(1).

${ }^{20}$ Ibid., at Art. 93(1)(k).

${ }^{21}$ I. Bantekas, 'The International Law on Terrorist Financing', in B. Saul (ed.), Research Handbook on International Law and Terrorism (2014), 121, at 132.

${ }^{22}$ F. Guariglia and G. Hochmayr, 'Article 57', in O. Triffterer and K. Ambos (eds.), The Rome Statute of the International Criminal Court: A Commentary (2016), 1421, at 1435.

${ }^{23}$ Ibid.

${ }^{24}$ Ibid.
} 
person has committed a crime within the jurisdiction of the Court', ${ }^{25}$ i.e., the same as required by Article 58(1)(a) of the Rome Statute. ${ }^{26}$ Should the 'strength of the evidence' no longer meet this threshold, the legal basis for any request issued pursuant thereto would cease to exist.

The 'strength of the evidence' has been strictly construed by the ICC. In Kenyatta, ICC Trial Chamber V(B) took the following factors into account before suspending the Pre-Trial Chamber's order to freeze the assets of Uhuru Muigai Kenyatta and others: ${ }^{27}$

... the Prosecution's acknowledgement that it 'now has insufficient evidence to secure a conviction at trial', that any information provided 'may or may not yield evidence relevant to this case', and the directive contained in Article 57(3)(e) of the Statute that the Chamber pay due regard to the strength of the evidence and the rights of the parties concerned $\ldots{ }^{28}$

This straightforward application of the 'evidentiary threshold' safeguard found in the text of Article 57(3)(e) of the Rome Statute is evidently paramount to the rights of the accused. When viewed in light of the Prosecutor's failure to bring sufficient evidence to secure a conviction in Kenyatta, the reasons behind the discomfort felt by a number of delegations when finalizing the text of the Rome Statute by the lack of a clear evidentiary threshold for the issuance of pre-trial protective measures ${ }^{29}$ become even more apparent. Without (the enforcement of) such a threshold, the measures might have remained in force despite the limited prospects of securing a conviction and, thereafter, an order for reparations.

\subsection{Prior notification and modification}

Further safeguards can be found in Rule 99 of the ICC RPE. First, Rule 99(2) of the ICC RPE provides that, where such notification could not 'jeopardize the effectiveness of the measures requested ... the Registrar shall provide notification of the proceedings to the person against whom a request is made and so far as is possible to any interested persons or interested States. ${ }^{30}$ Schabas argues that the person against whom a request is made may be the accused person, but 'may also be the person or body in possession of the items in question'. ${ }^{31}$ Parties other than accused persons, the Prosecutor, and victims may therefore benefit from this safeguard against the potential impact of protective measures. As Guariglia and Hochmayr observe, giving prior notification would appear to constitute the exception, rather than the rule. ${ }^{32}$ The reason behind this is evident: 'the success of the request depends on its being undisclosed to the person prosecuted by the Court'. ${ }^{33}$

Rule 99(3) of the ICC RPE alludes to a second safeguard, namely the possibility that an order requesting protective measures might be 'revoked or otherwise modified'. ${ }^{34}$ Where an order is made without prior notification under Rule 99(2), the person(s) against whom the request is made - as well as other interested persons and states - are invited to make observations as to the revocation or modification thereof 'as soon as is consistent with the effectiveness of the measures requested'. ${ }^{35}$

\footnotetext{
${ }^{25}$ Rome Statute, supra note 1, at Art. 58(1)(a).

${ }^{26}$ See Guariglia and Hochmayr, supra note 22, at 1435.

${ }^{27}$ Prosecutor v. Kenyatta, Decision Ordering the Registrar to Prepare and Transmit a Request for Cooperation to the Republic of Kenya for the Purpose of Securing the Identification, Tracing and Freezing or Seizure of Property and Assets of Francis Kirimil Muthaura, Uhuru Muigai Kenyatta and Mohammed Hussein Ali, ICC-01/09-02/11-42-Conf, P.T.Ch. I, 5 April 2011.

${ }^{28}$ Prosecutor v. Kenyatta, Decision on the implementation of the request to freeze assets, ICC-01/09-02/11-931, T.Ch. V(b), 8 July 2014, at para. 29 (Kenyatta Implementation Decision).

${ }^{29}$ See Guariglia and Hochmayr, supra note 22, at 1435.

${ }^{30}$ ICC, Rules of Procedure and Evidence, ICC-ASP/1/3 (ICC RPE), at Rule 99(2).

${ }^{31} \mathrm{~W}$. Schabas, The International Criminal Court: A Commentary on the Rome Statute (2016), at 884.

${ }^{32}$ See Guariglia and Hochmayr, supra note 22, at 1436.

${ }^{33}$ Ibid.

${ }^{34}$ ICC RPE, supra note 30, at Rule 99(3).

${ }^{35}$ Ibid.
} 


\subsection{The right to appeal}

A further due process guarantee available under the ICC legal framework is the right to request leave to appeal protective measures decisions pursuant to Article 82(1)(b) of the Rome Statute, which provides as follows: ' 1 . Either party may appeal any of the following decisions in accordance with the Rules of Procedure and Evidence: ... (b) A decision granting or denying release of the person being investigated or prosecuted. ${ }^{36}$ Though at first glance one might question how decisions granting or denying the release of accused persons relate to the identification, tracing and freezing or seizure of assets, this approach was confirmed by ICC Pre-Trial Chamber II in 2014. According to Judge Tarfusser:

in light of both its provisional nature and the fact that it relates to one of the fundamental rights of an accused, a decision on the seizure of assets can be considered as similar to a decision on the interim release of the accused, which decision can be appealed without the leave of the relevant Chamber pursuant to article 82(1) (b) of the Statute. ${ }^{37}$

Pre-Trial Chamber II also observed that 'a direct right to appeal is also enshrined in article 82(4) and rule 150(1) of the Rules against orders for reparations issued under article 75, which orders may also similarly affect the right to property, ${ }^{38}$ which, as noted above, it had explicitly acknowledged as a fundamental right protected by a series of international human rights instruments.

On 28 October 2008, Jean-Pierre Bemba Gombo applied for the release of additional seized funds, an earlier application having already been partially granted on 10 October $2008 .{ }^{39}$ Pre-Trial Chamber III dismissed Bemba's second application. ${ }^{40}$ Among other reasons, the Pre-Trial Chamber observed that the defence team had failed to 'request leave to appeal the Decision of 10 October $2008,{ }^{41}$ thereby giving weight to the appellate safeguarding mechanism enshrined in the Rome Statute and the ICC RPE. The right to appeal decisions concerning protective measures therefore serves two purposes: (1) affording a safeguard against orders against the assets of accused persons that reach beyond the limits imposed by the ICC's legal framework; and (2) preventing those whose assets have been subjected to freezing or seizure measures from making successive requests for their release without exhausting all legal avenues at their disposal under the Rome Statute and the ICC RPE.

\subsection{The 'rights of the parties concerned' and 'the ultimate benefit of victims'}

Article 21(3) of the Rome Statute stipulates that, in applying and interpreting the sources of law at its disposal, including the Statute and RPE, ${ }^{42}$ such application and interpretation 'must be consistent with internationally recognized human rights'. ${ }^{43}$ Both the Rome Statute and international human rights law guarantee a series of rights on the part of the accused, while Article 57(3)(e) explicitly refers to 'rights of the parties concerned', which has to include the Prosecutor as the second 'party' to the proceedings. The provision also makes reference to the 'ultimate benefit

\footnotetext{
${ }^{36}$ Rome Statute, supra note 1 , at Art. 82(1)(d).

${ }^{37}$ Prosecutor v. Bemba et al., Decision on Mr Kilolo's 'Notice of appeal against the decision of the Single Judge ICC-01/0501/13-743-Conf-Exp' dated 10 November 2014 and on the urgent request for the partial lifting of the seizure on Mr Kilolo's assets dated 24 November 2014, ICC-01/05-01/13-773, P.T.Ch. II, 1 December 2014, at 5 (Kilolo Notice Decision).

${ }^{38}$ Ibid.

${ }^{39}$ Prosecutor $v$ Bemba, Decision on the Defence's Application for Lifting the Seizure of Assets and Request for Cooperation to the Competent Authorities of Portugal, ICC-01/05-01/08-251-Anx, P.T.Ch. III, 10 October 2008 (Bemba First Lifting Decision).

${ }^{40}$ Prosecutor v. Bemba, Decision on the Second Defence's Application for Lifting the Seizure of Assets and Request for Cooperation to the Competent Authorities of the Republic of Portugal, ICC-01/05-01/08-249, P.T.Ch. III, 14 November 2008, at disposition (Bemba Second Lifting Decision).

${ }^{41}$ Ibid., at para. 24. See also ibid., at para. 62 .

${ }^{42}$ Rome Statute, supra note 1, at Art. 21(1)(a).

${ }^{43}$ Ibid., at Art. 21(3).
} 
of victims', who hold a unique and significant place in the Rome Statute system of international criminal justice. Finally, Article 93(1)(k) of the Rome Statute safeguards the rights of bona fide third parties in the execution of (pre-trial) enforcement measures with a view to eventual forfeiture. ${ }^{44}$ The interests of the principal stakeholders in the protective measures process will consequently be addressed in turn.

\subsubsection{Accused persons}

As the direct objects of the measures, accused persons' rights are clearly implicated by orders for protective measures for the purpose of forfeiture issued at the pre-trial phase. The rights implicated by such measures under Article 57(3)(e) of the Rome Statute include the right to family life. According to Sluiter, the application of human rights norms to the 'unique' circumstances of ICTs inevitably results in reduced protection for accused persons when compared to the interests of the prosecution and/or victims. ${ }^{45}$ It is possible that the freezing and seizure of assets in the name of an accused person, where the rights and interests of these three participants, as well as bona fide third parties, must be balanced, could lead to such an outcome, putting assets beyond the reach of the family members etc. of the person(s) against whom the protective measures are sought. Article 21(3) of the Rome Statute ought to provide a safeguard against the interpretation of Article 57(3)(e) in a manner inconsistent with, for example, the right to respect for private and family life. ${ }^{46}$ Other rights of the accused that could potentially be implicated by the imposition of pre-trial protective measures for the purpose of forfeiture include the right to the peaceful enjoyment of possessions ${ }^{47}$ and the right to a fair trial (i.e., to be defended by counsel of one's own choosing). ${ }^{48}$

The rights of the accused, as well as those of other interested stakeholders, could also be impacted by the ex parte status of requests or decision for protective measures concerning assets that may later be the object of forfeiture measures. Such potential prejudice was acknowledged by Trial Chamber I in Lubanga: 'ex parte procedures are only to be used exceptionally when they are truly necessary and when no other, lesser, procedures are available, and the court must ensure that their use is proportionate given the potential prejudice to the accused' ${ }^{49}$ This proportionality assessment must take into consideration the interests of victims in obtaining reparations in the event of a conviction as well as the interests of the Prosecutor in securing the effective execution of the measures requested. It is therefore difficult to contest the application of ex parte proceedings in order to safeguard the rights of the accused in the protective measures process, an argument underscored by the reality that the rights of the accused in terms of participation are fewer during the pre-trial phase of proceedings before the Court compared with the later stages thereof. $^{50}$

\footnotetext{
${ }^{44}$ Ibid., at Art. 93(1)(k).

${ }^{45}$ G. Sluiter, 'Human Rights Protection in the ICC Pre-Trial Phase', in C. Stahn and G. Sluiter (eds.), The Emerging Practice of the International Criminal Court (2009), 459, at 461.

${ }^{46}$ As protected in, e.g., 1950 Convention for the Protection of Human Rights and Fundamental Freedoms (ECHR), 213 UNTS 2889, at Art. 8.

${ }^{47}$ As protected in, e.g., 1952 Protocol 1 to the European Convention for the Protection of Human Rights and Fundamental Freedoms, 213 UNTS 262, at Art. 1. The protection of this fundamental right was also explicitly acknowledged by Pre-Trial Chamber II in Kilolo Notice Decision, supra note 37, at 5.

${ }^{48}$ As protected in, e.g., Rome Statute, supra note 1, at Art. 67(1)(b) and ECHR, supra note 46, at Art. 6.

${ }^{49}$ Prosecutor v. Lubanga, Decision on the procedures to be adopted for ex parte proceedings, ICC-01/04-01/06-1058, T.Ch. I, 6 December 2007.

${ }^{50}$ Compare the rights afforded to persons during an investigation under Rome Statute, supra note 1, at Art. 55 and those granted to the accused pursuant to Rome Statute, supra note 1, at Art. 67. On the application of the former see C. Hall and D. Jacobs, 'Article 55', in O. Triffterer and K. Ambos (eds.), The Rome Statute of the International Criminal Court: A Commentary (2016), 1394, at 1395-6.
} 


\subsubsection{The Prosecutor}

As noted by Judge Hunt in the Milošević and others Decision, ${ }^{51}$ the primary function of an order to freeze the assets of an accused person is to facilitate their arrest. Indeed, it is possible to imagine a scenario where an offer to unfreeze the assets of an accused person who remains at large could be utilized as a tool to negotiate voluntary surrender.

Asset freezing can also disrupt ongoing and prevent future criminal conduct within the jurisdiction of the ICC. The commission of international crimes frequently goes hand-in-hand with the purchase of weapons and supplies, payments to troops, as well as other potentially lucrative activities, including the trafficking of persons, arms, and narcotics, all of which require the availability of - and access to - (financial) assets.

In addition, financial records may provide evidentiary links between individuals and/or groups, which can assist the Prosecutor in proving, for example, the aiding and abetting of crimes. Such records can be obtained through the identification of assets belonging to accused persons pursuant to the procedures in Article 93(1)(k) of the Rome Statute.

Discussing the role of the Prosecutor with respect to measures under Article 57(3)(e) of the Rome Statute, Pre-Trial Chamber I, having noted that the Prosecutor had not, at the time of its Decision, transmitted requests for co-operation to states parties with respect to identifying, tracing, or seizing Lubanga's assets, expressed 'the view that, as the organ of the Court primarily in charge of the investigation ... the effectiveness of the reparation system would greatly benefit from the Prosecution's due consideration of this matter during the investigation stage. 52

The interests of the Prosecutor in requesting protective measures during the investigative phase, in the view of Pre-Trial Chamber I, are therefore also linked to future reparations, which may later be found to be payable to victims if the accused is found guilty. It is to the interests of the victims of the crimes at issue that the following section will turn.

\subsubsection{Victims}

Victims play a prominent role in proceedings at the ICC, with broader rights than those afforded by earlier ICTs. The International Military Tribunal (IMT) established at Nuremberg, with substantial input from American jurists, focused on punishing individuals for mass crimes within a predominantly adversarial framework. ${ }^{53}$ However, after the Cold War, victim-oriented provisions were included in the legal frameworks of a number of ICTs and, most significantly for the purposes of the present article, that of the permanent ICC. The post-Cold War era also saw significant developments in international human rights law, including recognition that victims of serious violations have a right to reparation. ${ }^{54}$ Evans identifies 'growing attention to victims within national criminal justice systems and ... a reaction to criticism of the manner in which victims' concerns were considered by the ICTY and the ICTR' as influential factors leading to the adoption of the Court's victim reparations regime. ${ }^{55}$ As Zegveld observes:

With the establishment of the ICC, for the first time in history, individuals can submit claims of a private law nature to an international court. In contrast to the ICTY and ICTR, the ICC may award reparations for the benefit of individual victims. It may do so directly against a convicted person. This reparation may take the form of restitution,

\footnotetext{
${ }^{51}$ Milošević and others Decision, supra note 12, at para. 27.

${ }^{52}$ Prosecutor v. Lubanga, Decision on the Prosecutor's Application for a warrant of arrest, Article 58, ICC-01/04-01/06-1Corr-Red, P.T.Ch. I, 10 February 2006, at para. 141 (Lubanga Arrest Warrant Decision).

${ }^{53}$ See L. Zegveld, 'Victims' Reparations Claims and International Criminal Courts: Incompatible Values?', (2010) 8 JICL 79 , at 86-7. The International Military Tribunal for the Far East (IMTFE) reprised this largely retributive model.

${ }^{54}$ See, e.g., C. Evans, The Right to Reparation in International Law for Victims of Armed Conflict (2012).

${ }^{55}$ Ibid., at $87-8$.
} 
compensation and rehabilitation. The ICC can act on an application of a victim or exceptionally on its own motion. ${ }^{56}$

Although not full parties to the proceedings before the ICC in the same way as victims are able to participate before certain national courts or at other ICTs, including the EAC and the Extraordinary Chambers in the Courts of Cambodia (ECCC), the interests of victims are evidently paramount to the protective measures procedures found in Article 57(3)(e) of the Rome Statute and Rule 99(1) of the ICC RPE.

\subsubsection{Bona fide third parties}

Article $93(1)(\mathrm{k})$ of the Rome Statute explicitly provides that states parties are obliged to assist the Court in identifying, tracing, freezing, and seizing assets 'without prejudice to the rights of bona fide third parties'. ${ }^{57}$ However, these rights are not further elaborated in the Rome Statute or the ICC RPE. ${ }^{58}$ Nevertheless, such third parties constitute a relevant category of stakeholders in the pre-trial protective measures process. For example, their interests, not least their right to the peaceful enjoyment of possessions, could be implicated in two situations. First, the third parties could be in possession of asset(s) belonging to the accused person(s), which could consequently be subjected to pre-trial protective measures. Second, the third parties could have a right in property which, at the time the ICC requests protective measures, is in the hands of the accused. Goldsmith and Linderman claim that such third parties could include owners, creditors, purchasers, business partners, and joint tenants, among others. ${ }^{59}$ The interests of bona fide third parties must consequently also be safeguarded alongside those of the accused, the Prosecutor, and any potential victims. The following section aims to provide an examination of how the ICC has given effect to these rights and interests and, where they are in competition, how it has sought to balance them in its decisions involving persons accused of committing crimes under its jurisdiction.

\section{The ICC practice}

Much of the Court's practice regarding pre-trial 'protective measures for the purpose of forfeiture' remains confidential. However, pre-trial chambers have issued requests for such measures against Thomas Lubanga Dyilo, ${ }^{60}$ Germain Katanga, ${ }^{61}$ Jean-Pierre Bemba Gombo, ${ }^{62}$ Uhuru Muigai

\footnotetext{
${ }^{56}$ Zegveld, supra note 53 , at 88.

${ }^{57}$ Rome Statute, supra note 1, at Art. 93(1)(k).

${ }^{58}$ See M. Stiel and C. -F. Stuckenberg, 'Article 109: Enforcement of fines and forfeiture measures', in M. Klamberg (ed.), Commentary on the Law of the International Criminal Court (2017), 704, at 705, note 810: 'The only ground for refusal to enforce fines and forfeiture orders mentioned in the Statute is prejudice to the "rights of bona fide third parties", an expression nowhere defined in the Statute or RPE. Hence, it seems that national courts have to determine which rights are relevant and when a party qualifies as bona fide, which not only deviates from inter-State practice but may result in an uneven application.' See also K. Ambos, Treatise on International Criminal Law Volume III: International Criminal Procedure (2016), at 655-6.

${ }^{59}$ M. Goldmsith and M. J. Linderman, 'Asset Forfeiture and Third Party Rights: The Need for Further Law Reform', (1989) 5 DukeLJ 1254, at 1257.

${ }^{60}$ See Prosecutor v. Lubanga, Request to the Democratic Republic of the Congo for the purpose of obtaining the identification, tracing, freezing and seizure of property and assets belonging to Mr. Thomas Lubanga Dyilo, ICC-01/04-01/06-22-tEN, P.T.Ch. I, 9 March 2006; Prosecutor v. Lubanga, Request to States Parties to the Rome Statute for the Identification, Tracing and Freezing or Seizure of the Property and Assets of Mr Thomas Lubanga Dyilo, ICC-01/04-01/06-62-tEN, P.T.Ch. I, 31 March 2006.

${ }^{61}$ See Prosecutor v. Katanga, Request to the Democratic Republic of the Congo for the purpose of obtaining the identification, tracing, freezing and seizure of the property and assets of Germain Katanga, ICC-01/04-01/07-7-tENG, P.T.Ch. I, 7 August 2007.

${ }^{62}$ Prosecutor v. Bemba, Decision and Request to the Republic of Portugal for the purpose of obtaining the identification, tracing, freezing and seizure of property and assets, ICC-01/05-01/08-8, P.T.Ch. III, 27 May 2008 (Bemba Seizure Decision).
} 
Kenyatta and others, ${ }^{63}$ and Aimé Kilolo Musamba. It was also reported in November 2011, by then ICC Prosecutor Moreno Ocampo, to the UN Security Council, that ' $\mathrm{t}$ ] he Court ha[d] sent ... requests for assistance to Libya, State Parties, and five UN Security Council non-State Parties to identify, trace, seize and freeze all the personal assets belonging to the suspects', ${ }^{64}$ namely Saif Al-Islam Gaddafi and Abdullah Al-Senussi. ${ }^{65}$ The following section will examine the practice of the Court with respect to requests for measures under Article 57(3)(3) of the Rome Statute and the relevant RPE, to the extent that its decisions and orders have been classified as public.

\subsection{The purpose of protective measures and the range of assets susceptible thereto}

Article 93(1)(k) of the Rome Statute, which governs forms of co-operation that the Court can request from states parties, does not explicitly provide that the latter should assist the Court in identifying, tracing, freezing, and seizing assets for the purpose of reparations; rather, such measures can be requested 'for the purpose of eventual forfeiture'. ${ }^{66}$ This said, Article 57(3)(e) of the Rome Statute explicitly refers to the 'ultimate benefit of victims' in the context of the pre-trial chamber requesting 'protective measures for the purpose of forfeiture' pursuant to Article 93(1)(k). ${ }^{67}$ On a restrictive reading of Articles 93(1)(k) and 57(3)(e) of the Rome Statute, one could conclude that such measures ought to be targeted only at ensuring the enforcement of the penalty of forfeiture in the event of a conviction. Such a narrow reading would have accorded minimal weight to the 'ultimate benefit of victims' in the pre-trial protective measures process, other than those who might have a claim to forfeited 'proceeds, property and assets derived directly or indirectly' from the crime(s) of which the accused was convicted in accordance with the forfeiture procedures contained in the Rome Statute. ${ }^{68}$ Such an interpretation was considered, but ultimately rejected, by Pre-Trial Chamber I in Lubanga, ${ }^{69}$ which instead opined as follows:

As the power conferred on the Court to grant reparations to victims is one of the distinctive features of the Court, intended to alleviate, as much as possible, the negative consequences of their victimization, it will be in the "ultimate interest of victims" if pursuant to article 57 (3) (e) (of the Rome Statute), the cooperation of States Parties can be sought in order to take protective measures for the purpose of securing the enforcement of a future reparation award.

In the Chamber's view, the reparation scheme provided for in the Statute is not only one of the Statute's unique features. It is also a key feature. In the Chamber's opinion, the success of the Court is, to some extent, linked to the success of its reparation system. In this context, the Chamber considers that early tracing, identification and freezing or seizure of the property

\footnotetext{
${ }^{63}$ Prosecutor v. Kenyatta, Decision Ordering the Registrar to Prepare and Transmit a Request for Cooperation to the Republic of Kenya for the Purpose of Securing the Identification, Tracing and Freezing or Seizure of Property and Assets of Francis Kirimi Muthaura, Uhuru Muigai Kenyatta and Mohammed Hussein Ali, ICC-01/09-02/11-42, P.T.Ch. II, 5 April 2011 (Kenyatta Seizure Order).

${ }^{64}$ L Moreno-Ocampo, 'Prosecutor's statement to the United Nations Security Council on the situation in Libya, pursuant to UNSCR 1970 (2011)', 2 November 2011, available at www.icc-cpi.int/Pages/item.aspx?name=statement $\% 20$ by $\% 201$ uis $\%$ 20 moreno_ocampo $\% 20$ prosecutor\%20of\%20the $\% 20$ international $\% 20$ criminal $\% 20$ court $\% 20 \mathrm{t}$.

${ }^{65}$ Ibid.

${ }^{66}$ Rome Statute, supra note 1, at Art. 93(1)(k).

${ }^{67}$ Ibid., at Art. 57(3)(3).

${ }^{68}$ Ibid., at Art. 77(2): 'In addition to imprisonment, the Court may order: ... (b) A forfeiture of proceeds, property and assets derived directly or indirectly from that crime, without prejudice to the rights of bona fide third parties.'

${ }^{69}$ Lubanga Arrest Warrant Decision, supra note 52, at para. 132: 'The Chamber notes that, although a first reading of article $57(3)(e)$ of the Statute might lead to the conclusion that cooperation requests for the taking of protective measures under such a provision can be aimed only at guaranteeing the enforcement of a future penalty of forfeiture under article $77(2)$ of the Statute, the literal interpretation of the scope of such provision is not clear, because of the reference to the "ultimate benefit of the victims"'.
} 
and assets of the person against whom a case is launched through the issuance of a warrant of arrest or a summons to appear is a necessary tool to ensure that, if that person is finally convicted, individual or collective reparation awards ordered in favor of victims will be enforced. Should this not happen, the Chamber finds that by the time an accused person is convicted and a reparation award ordered, there will be no property or assets available to enforce the award.

In the Chamber's view, existing technology makes it possible for a person to place most of his assets and moveable property beyond the Court's reach in only a few days. Therefore, if assets and property are not seized or frozen at the time of the execution of a co-operation request for arrest and surrender, or very soon thereafter, it is likely that the subsequent efforts of the Pre-Trial Chamber, the Prosecution or the victims participating in the case will be fruitless. ${ }^{70}$

But this conclusion by Pre-Trial Chamber I was not the end of the matter, with the issue again coming to prominence in the case against Kenyatta and others.

Following disclosure to the public of confidential information, including to the accused, Uhuru Muigai Kenyatta, on 21 October 2014, ICC Trial Chamber V(b) reclassified as public a series of documents concerning pre-trial protective measures in the cases in the Situation in the Republic of Kenya. ${ }^{71}$ On 5 April 2011, in the case against Francis Kirimi Muthaura, Uhuru Muigai Kenyatta, and Mohammed Hussein Ali, Pre-Trial Chamber II ordered the Registrar, in consultation with the Prosecutor, to request co-operation from Kenya 'for purposes of identifying, tracing and freezing or seizing the property and assets belonging to or under the control of Francis Kirimi Muthaura, Uhuru Muigai Kenyatta and Mohammed Hussein Ali, without prejudice to the rights of bona fide third parties' and to regularly inform the Chamber of any action taken in the execution of this order. ${ }^{72}$

However, the Government of the Republic of Kenya refused to execute the order. In its submissions, the Kenyan Government expressed the following view:

... the Pre-Trial Chamber's Order lacks legal basis and should be revoked. It reiterated its view that Articles 93(1)(k) and 57(3)(e) of the Statute, as well as Rule 99 of the Rules, read together, provide three basic pre-requisites which must be satisfied prior to making a request for cooperation under these provisions: (i) that the criminal offences have been proven, after a full trial; (ii) that the Court found that the person obtained the proceeds, property and assets directly or indirectly from the commission of the crime: and/or (iii) that in committing the crime the accused person employed the property and assets identified. ${ }^{73}$

Trial Chamber V(b), by majority, Judge Henderson dissenting, rejected the submission that, when requesting protective measures, a nexus is required between the assets and the commission of the crime(s). According to the Trial Chamber:

\footnotetext{
${ }^{70}$ Ibid., at paras. $135-7$ (footnotes omitted). See also Prosecutor v. Lubanga, Decision Establishing the Principles and Procedures to be Applied to Reparations, ICC-01/04-01/06-2904, T.Ch. I, 7 August 2012, at para. 277: 'The identification and freezing of any assets of the convicted person are a fundamental element in securing effective reparations, and pursuant to Article $93(\mathrm{l})(\mathrm{k})$ of the Statute, State Parties should provide the Court with timely and effective assistance at the earliest possible stage of the proceedings.'

${ }^{71}$ Prosecutor v. Kenyatta, Order concerning the public disclosure of confidential information, ICC-01/09-02/11-967, T.Ch. V(b), 21 October 2014.

${ }^{72}$ Kenyatta Seizure Order, supra note 63, at disposition.

${ }^{73}$ Kenyatta Implementation Decision, supra note 28, at para. 10, citing Prosecutor v. Kenyatta, Submissions of the Government of the Republic of Kenya pursuant to the 'Order for Submissions on the Implementation of the Request regarding the Freezing of Assets', ICC-01/09-02/11-923-Conf-Corr, T.Ch. V(b), 28 May 2014, at para. 12.
} 
The Majority observes that Article 93(1)(k) of the Statute is broadly phrased and allows a Chamber to request cooperation from a State in implementing protective measures in respect of proceeds, property and assets, and 'instrumentalities of crimes'. The text makes no distinction concerning whether such property or assets must have been derived directly or indirectly from a crime, as explicitly required under Article 77(2)(b) of the Statute. Read plainly, a request for protective measures in respect of property or assets does not require a nexus between the crimes for which the accused is summoned, charged or convicted, unless it is made solely for the purposes of Article 77(2)(b) of the Statute. In addition, even in those circumstances, any determinative finding as to actual nexus between the proceeds, property or assets in question and crimes could only be made under Article 77(2)(b) of the Statute after conviction. ${ }^{74}$

In Kenyatta, Trial Chamber V(b) adopted a broad interpretation of the Rome Statute and RPE in confirming that assets subject to protective measures include those without any nexus to the crimes of which the accused person is suspected, unlike proceeds, property, and assets susceptible to the penalty of forfeiture, which, pursuant to Article $77(2)(\mathrm{b})$ of the Rome Statute, have to be 'derived directly or indirectly from that crime'. ${ }^{75}$ However, in his Dissenting Opinion, Judge Henderson expressed the view that Article 57(3)(e) of the Rome Statute and Rule 99(1) of the ICC RPE do not allow the pre-trial chamber to request protective measures for the purpose of an order for reparations, ${ }^{76}$ presenting a challenge to the Court's earlier findings in Lubanga. According to Judge Henderson:

I do not read the phrase "in particular for the ultimate benefit of victims" contained in Article 57(3)(e) of the Statute as expanding the authority of the Pre-Trial Chamber under that Article beyond that which is expressly stated. Rather, I see this phrase as an acknowledgment that in taking the significant step of prospectively freezing or seizing the property or assets of a person who is presumed innocent, the Pre-Trial Chamber shall take into consideration - in addition to the strength of the evidence and the rights of the accused person - whether such measures would in particular be for the ultimate benefit of the victims ... In my view, this objective can be effectively achieved by the Pre-Trial Chamber requesting protective measures for the purposes of eventual forfeiture, which in appropriate circumstances can be transferred to the Trust Fund and thereafter used for the benefit of the victims in an award for reparations, as provided in the plain text of Article 57(3)(e) of the Statute. ${ }^{77}$

Here, Judge Henderson questions the broad interpretation given to the pre-trial protective measures procedures in the Rome Statute and RPE by the majority of Trial Chamber V(b) in Kenyatta, whose view is consistent with that adopted by Pre Trial Chamber I in the Lubanga and Katanga cases. Judge Henderson's concern is valid. Though the reading of Article 57(3)(e) of the Rome Statute adopted in the Court's earlier case law broadens the range of assets susceptible to protective measures with a view to funding potential future reparations, this has implications for accused persons, who, at the pre-trial stage, must be presumed innocent and remain entitled to the peaceful enjoyment of their possessions.

In Kilolo, Judge Schmitt, on behalf of Trial Chamber VII, interpreted Article 57(3)(e) of the Rome Statute in the same manner as Pre-Trial Chamber I in Lubanga and the majority of

\footnotetext{
${ }^{74}$ Kenyatta Implementation Decision, supra note 28, at para. 16.

${ }^{75}$ Rome Statute, supra note 1, at Art. 77(2)(b).

${ }^{76}$ Prosecutor v. Kenyatta, Dissenting Opinion of Judge Henderson, ICC-01/09-02/11-931-Anx, T.Ch. V(b), 8 July 2014.

${ }^{77}$ Ibid., at paras. 5,7 .
} 
Trial Chamber $\mathrm{V}(\mathrm{b})$ in Kenyatta, thereby refusing to endorse the narrower interpretation proposed by Judge Henderson in his Dissenting Opinion in the latter case. ${ }^{78}$

The issue was ultimately settled by the Appeals Chamber, which confirmed the approach of the Kenyatta majority, in February 2016. ${ }^{79}$ Importantly, the Appeals Chamber notes that 'the freezing of assets constitutes a provisional protective measure which must be applied in a manner consistent with Article 21(3) of the Statute' ${ }^{80}$ It might therefore be expected that when such measures are imposed or subject to review, the chamber in question would take the rights and interests of the accused and any bona fide third parties, as well as the ultimate benefit of victims, into consideration. Particularly persuasive in the judgment of the Appeals Chamber is its discussion of the object and purpose of the Rome Statute as it pertains to reparations to victims. ${ }^{81}$ Unlike the ICTY, ICTR, and SCSL, all of which had the power to order protective measures but where victims could only claim compensation 'in a national court or other competent body', ${ }^{82}$ the ICC is authorized by Article 75 of the Rome Statute to order reparations directly to the victims of crimes under its jurisdiction. $^{83}$

After observing that the Rome Statute also provides for an enforcement mechanism under Article 75(4) and Article 109 of the Rome Statute, ${ }^{84}$ the Appeals Chamber concluded:

an interpretation of the Statute that brings the property and assets of the suspect or accused person that will be potentially subject to reparations orders in the event of conviction within the scope of protective measures under Articles 57 (3) (e) and 93 (1) (k) of the Statute consolidates the effectiveness of the reparations system and is thus consistent with the object and purpose of the Statute. ${ }^{85}$

By clarifying the interpretation of these provisions, the Appeals Chamber has given legal certainty to the implicated stakeholders. According to Ferstman, the decision of the majority in Kenyatta, and, it is argued, its confirmation by Judge Schmitt in Kilolo and by the Appeals Chamber, was 'a progressive interpretation of the statutory framework which should encourage legal representatives of victims to actively engage with the OTP and the relevant chambers on the issue of asset orders, for the ultimate benefit of victims' ${ }^{86}$ In other words, by broadly interpreting the protective measures provisions in the Rome Statute and ICC RPE to take into account orders for reparations, the Court has demonstrated its commitment to the ultimate benefit of victims in Article 57(3)(e) of the Rome Statute. The following section examines how the Court has balanced this consideration with the rights and interests of other stakeholders in the pre-trial protective measures process.

\subsection{Balancing competing rights and interests in the protective measures process}

The ultimate benefit of victims may be in direct competition with the rights and interests accruing to other parties concerned in the Article 57(3)(e) process. Competing rights and interests can be

\footnotetext{
${ }^{78}$ Prosecutor v. Bemba et al., Decision on the 'Requête de la défense aux fins de levée du gel des avoirs de Monsieur Aimé Kilolo Musamba', ICC-01/05-01/13-1485-Red, T.Ch. VII, 17 November 2015 (Kilolo Lifting Decision), at paras. 17-18.

${ }^{79}$ Prosecutor v. (Redacted), Judgment on the appeal of the Prosecutor against the decision of (REDACTED), ICC-ACRed01/16, A.Ch., 15 February 2016.

${ }^{80}$ Ibid., at para. 53.

${ }^{81} \mathrm{Ibid}$.

${ }^{82}$ Ibid., citing ICTY RPE, supra note 11, at Rule 106 (B); ICTR RPE, supra note 11, at Rule 106 (B); SCSL RPE, supra note 5, at Rule $105(\mathrm{~B})$.

${ }^{83}$ Ibid., referring to Rome Statute, supra note 1, at Art. 75 and ICC RPE, supra note 30, at Rule 94.

${ }^{84}$ Ibid., referring to Rome Statute, supra note 1, at Arts. 75(4), 109.

${ }^{85}$ Ibid.

${ }^{86} \mathrm{C}$. Ferstman, 'Cooperation and the International Criminal Court: The Freezing, Seizing and Transfer of Assets for the Purpose of Reparations', in O. Bekou and D. J. Birkett (eds.), Cooperation and the International Criminal Court: Perspectives from Theory and Practice (2016), 227, at 236.
} 
identified most clearly in the Court's case law as between the Prosecutor and victims on the one hand and accused persons and their family members on the other. While the Prosecutor and victims may have a shared interest, albeit perhaps for different reasons, in seeing protective measures ordered (or maintained), accused persons and their dependents may have reasons to request that such measures be denied (or rescinded). In cases where rights and interests are found to be in competition, the Court is able to apply the legal framework at its disposal in order to strike a fair balance between them.

On 24 May 2008, Mr Jean-Pierre Bemba Gombo was arrested near Brussels by Belgian authorities following the issuance of an arrest warrant by the ICC. ${ }^{87}$ On 27 May 2008, four days after his arrest warrant was issued, ICC Pre-Trial Chamber III, noting, inter alia, Article 57(3)(e) of the Rome Statute and Rule 99(1) of the RPE, issued a request for co-operation to Portugal to identify, trace, freeze, and seize any property and assets belonging to Bemba located on its territory, subject to the rights of bona fide third parties. ${ }^{88}$

Bemba's application for legal assistance having been rejected because he was found not to be indigent, ${ }^{89}$ his defence counsel requested a partial lifting of the seizure order. ${ }^{90}$ On 10 October 2008, Pre-Trial Chamber III requested the competent Portuguese authorities 'to authorise temporarily the release of the amount of $€ 36,260$ on a monthly basis from (Bemba's) account [REDACTED] in Portugal as of 1 October 2008 until a decision on the confirmation of charges has been issued'. ${ }^{91}$ These funds were released (i) to enable Bemba to cover fees payable to his defence team and (ii) to support his family. Pre-Trial Chamber III reasoned as follows:

As to the expenses for the Defense of Mr Jean-Pierre Bemba, the Chamber underlines that the disclosure process has just started. The Chamber takes note that the Defence team has to analyse in a short period of time a significant amount of documents. The Chamber considers that at this stage of the proceedings, it is critical that the Defence has adequate time and facilities for the preparation of the confirmation hearing which is scheduled to take place on 4 November 2008.

Furthermore, as to the expenses of Mr Jean-Pierre Bemba to support his family, the Chamber acknowledges that he has financial obligations to his family and must be able to pay for the basic needs of his wife and children. ${ }^{92}$

Although Pre-Trial Chamber III did not engage in a lengthy discussion of the right(s) of the accused at issue, i.e., the rights to respect for private and family life and to a fair trial, respectively, ${ }^{93}$ it can be argued that its acknowledgment of Bemba's familial obligations and the 'needs of his wife and children' implicitly recognizes this right, guaranteed under international human rights law and, consequently, Article 21(3) of the Rome Statute. This is not to say that a more extensive discussion of the rights of the accused was necessarily merited in the case at hand. Because Bemba's application for lifting the freezing of assets remains confidential at the time of writing, it cannot be discerned whether he alleged any violation thereof. The manner in which this issue

\footnotetext{
${ }^{87}$ Prosecutor v. Bemba, Warrant of Arrest for Jean-Pierre Bemba Gombo, ICC-01/05-01/08-1-tENG, P.T.Ch. III, 23 May 2008.

${ }^{88}$ Bemba Seizure Decision, supra note 62, at para. 4 and disposition.

${ }^{89}$ Prosecutor v. Bemba, Registrar's Decision on the Application for Legal Assistance paid by the Court Filed by Mr Jean- Pierre Bemba Gombo, ICC-01/05-01/08-76-tENG, P.T. Ch. III, 25 August 2008.

${ }^{90}$ Prosecutor v. Bemba, Application for Lifting the Seizure, ICC-01/05-01/08-81-Conf-tENG, P.T.Ch. III, 26 August 2008.

${ }^{91}$ Bemba First Lifting Decision, supra note 39, at disposition.

${ }^{92}$ Ibid., at paras. $15-16$.

${ }^{93} \mathrm{Cf}$. the extensive discussion of the jurisprudence of the European Court of Human Rights by the ICC Presidency in Prosecutor v. Bemba, Reasons for the decision on the Applications for judicial review of Mr Jean-Pierre Bemba Gombo of 10 and 11 November 2008, ICC-01/05-01/08-310, Presidency, 5 December 2008, at paras 32-43.
} 
was addressed by the Court thus cannot be found wanting in this respect. Nor can it be claimed that the Decision fails to take the rights afforded to Bemba and his family under international human rights law seriously.

This issue again came to light in Bemba's request for the release of further seized funds. According to Pre-Trial Chamber III's decision disposing of the application:

Firstly, counsels of Mr Jean-Pierre Bemba requested the lifting of seizure or freezing of $€$ 78,900 on a monthly basis starting on 1 October 2008 to cover both his financial obligations to his family as well as to his counsels. Secondly, the Defence estimated that it would need $€ 100,000$ to cover its investigation activities. Thirdly, the Defence requested $€ 234,000$ in order to cover Mr Jean-Pierre Bemba's family expenses and his counsels' fees from the date of his arrest in the Kingdom of Belgium until September $2008 .{ }^{94}$

Pre-Trial Chamber III rejected Bemba's application, ${ }^{95}$ emphasizing that he had failed to 'demonstrate any change of circumstances in [his] financial situation ... since 10 October 2008 and ... support [his] Second Application with any documentation such as official invoices' ${ }^{96}$ It can therefore be reasonably assumed that, had Bemba demonstrated such a change in his circumstances (i.e., presumably to his detriment), supported by sufficient documentary evidence, the Pre-Trial Chamber might not have dismissed his application. This seems to be a perfectly reasonable application of the legal framework, balancing the interests of the accused (and his family) with those of the Prosecutor and victims.

This balance again came to the fore in the case against Jean-Pierre Bemba Gombo, Aimé Kilolo Musamba, Jean-Jacques Mangenda Kabongo, Fidèle Babala Wandu and Narcisse Arido, specifically as concerns Mr Kilolo, a former member of Bemba's defence team.

On 20 November 2013, Judge Tarfusser, designated as single judge on behalf of ICC Pre-Trial Chamber II, ordered the arrest of Jean-Pierre Bemba Gombo, Aimé Kilolo Musamba, JeanJacques Mangenda Kabongo, Fidèle Babala Wandu, and Narcisse Arido for their alleged commission of offences against the administration of justice. ${ }^{97}$ Pursuant to this order, Belgium seized a bank account under its jurisdiction in Kilolo's name. ${ }^{98}$ Kilolo's defence argued that the seizure of his assets was contrary to the Rome Statute. Among other reasons, he submitted that the seizure infringed his right to family life. ${ }^{99}$

Judge Schmitt, sitting as single judge, rejected Kilolo's request in its entirety. ${ }^{100}$ As to Kilolo's argument that the seizure of his assets violated his right to family life, Judge Schmitt reasoned as follows:

As a provisional measure under Article 57(3)(e) of the Statute, the freezing of assets (and its maintenance) must be applied in a manner consistent with Article 21(3) of the Statute. The single judge is attentive to Mr Kilolo's argument that the (maintenance of) seizure of said bank account would infringe his right to family life insofar as he purportedly cannot meet his financial obligations towards his family, including his young children. However ... the single judge is unconvinced that this provisional measure infringes upon Mr Kilolo's right to family life. The single judge recalls that the measure was justified as it was taken in

\footnotetext{
${ }^{94}$ Bemba Second Lifting Decision, supra note 40 , at para. 8.

${ }^{95}$ Ibid., at disposition.

${ }^{96}$ Ibid., at para. 24.

${ }^{97}$ Prosecutor v. Bemba et al., Warrant of arrest for Jean-Pierre Bemba Gombo, Aimé Kilolo Musamba, Jean-Jacques Mangenda Kabongo, Fidèle Babala Wandu and Narcisse Arido, ICC-01/05-01/13-1-tENG, P.T.Ch. II, 20 November 2013.

${ }^{98}$ Kilolo Lifting Decision, supra note 78 , at para. 2.

${ }^{99}$ Ibid., at para. 15, referring to Prosecutor v. Bemba et al., Addendum à la 'Requête de la défense aux fins de levée du gel des avoirs de Monsieur Aimé Kilolo Musamba', ICC-01/05-01/13-1014-Conf-Exp, T.Ch. VII, 28 July 2015, at paras. 15, 28.

${ }^{100}$ Kilolo Lifting Decision, supra note 78 , at disposition.
} 
accordance with the law and for a legitimate aim ... The single judge also finds that the measure is proportionate vis-à-vis the legitimate aim pursued. ${ }^{01}$

In Kilolo, unlike in Bemba, Trial Chamber VII explicitly confirmed that, in applying and interpreting Article 57(3)(e) of the Rome Statute and Rule 99(1) of the ICC RPE, both of which are primary sources of law under Article 21(1) of the Rome Statute, the ICC must take steps to ensure their consistency with 'internationally recognized human rights', ${ }^{102}$ an important safeguard in the protective measures process. Judge Schmitt, in keeping with the Court's general practice, ${ }^{103}$ followed the approach of the European Court of Human Rights (ECtHR) with regard to limiting the exercise of the right, in this instance, to the peaceful enjoyment of (private and) family life. In other words, he assessed whether the protective measure: (i) 'was taken in accordance with the law'; ${ }^{104}$ (ii) 'for a legitimate aim'; ${ }^{105}$ and (iii) whether it was 'proportionate' to that aim. ${ }^{106}$ Here, Judge Schmitt uses the approach of the ECtHR to interpret Article 21(3) of the ICC Statute and his reasons for rejecting Kilolo's request are numerous and clear. According to Judge Schmitt:

Mr Kilolo was released from detention in October 2014 and joined his family in Belgium. He also confirms that he resumed his profession as a lawyer in Brussels. Mr Kilolo is not subjected to any condition which unreasonably impedes the exercise of his profession and, thus, provide for his family. No further specific arguments are provided which demonstrate that Mr Kilolo lacks the means to support his family financially. As a result, the single judge finds that Mr Kilolo's right to family life is not unduly interfered with. ${ }^{107}$

As to Kilolo's request for a partial lifting of the seizure order, Judge Schmitt rejected the request as inappropriate. He reasoned:

As explained above, Mr Kilolo's personal circumstances allow him to provide for his family. Considering the amount seized, a monthly release of [REDACTED] would significantly reduce the sum contained in said bank account, thus rendering the provisional measure meaningless. No other measures appear available which would adequately ensure that the Court's interests underlying the seizure order would still be protected in the event that the seizure were to be partially lifted. ${ }^{108}$

Though the Single Judge rejected the accused's request, it cannot be said that the ultimate benefit of victims was unfairly prioritized above the rights of the accused and his family members in this Decision. Judge Schmitt identifies a number of legitimate aims pursued by the protective measures ordered against Kilolo. These include the need to preserve the assets for the enforcement of a possible penalty of forfeiture in the future, ${ }^{109}$ to meet any potential obligations on Kilolo's part vis-à-vis

\footnotetext{
${ }^{101}$ Kilolo Lifting Decision, supra note 78, at paras. 21-2 (footnotes omitted).

${ }^{102}$ Kilolo Lifting Decision, supra note 78, at para. 21.

${ }^{103}$ On which see A. Jones, 'Insights Into an Emerging Relationship: Use of Human Rights Jurisprudence at the International Criminal Court', (2016) 16 HRLRev 701, at 724; N. Croquet, 'The International Criminal Court and the Treatment of Defence Rights: A Mirror of the European Court of Human Rights' Jurisprudence?', (2011) 11 HRLRev 91; and V. Nerlich, 'Article 21 (3) of the ICC Statute: Identifying and Applying "Internationally Recognized Human Rights"', in P. Lobba and T. Mariniello (eds.), Judicial Dialogue on Human Rights: The Practice of International Criminal Tribunals (2017), 73, at 82.

${ }^{104}$ Kilolo Lifting Decision, supra note 78 , at para. 22

${ }^{105}$ Ibid.

${ }^{106}$ Ibid.

${ }^{107}$ Ibid.

${ }^{108}$ Ibid., at para. 23.

${ }^{109}$ Ibid., at para. 17.
} 
'other types of forfeiture', i.e., an order for reparations, ${ }^{110}$ to secure the assets in order to meet potential fine orders of the Court', 111 and to enable the ICC to recover the costs of Kilolo's legal assistance should he be found to have had the means to cover such expenses. ${ }^{112}$ Judge Schmitt then reasons that Kilolo is able to continue his work as a lawyer, the proceeds of which he deems sufficient for the support supporting his family, ${ }^{113}$ rendering the protective measures proportionate to these aims. Finally, the Single Judge observes that no measure other than the continued seizure of Kilolo's assets would protect 'the Court's interests underlying the seizure order'. ${ }^{114}$ In other words, the interests of the Prosecutor (in enforcing potential future fines and orders for forfeiture) and the ultimate benefit of victims (in seeing that reparations awards are enforced in the event of a conviction) can only be safeguarded through the maintenance of the protective measures. On the other hand, in the view of Judge Schmitt, the interests of Kilolo in meeting his financial obligations towards his family can be met through the continued exercise of his profession, which is not inhibited by the ongoing seizure of his assets. Had Kilolo shown that he lack[ed] the means to support his family financially, ${ }^{115}$ it would appear reasonable to assume that Judge Schmitt would have decided otherwise.

The ICC's publicly available case law with respect to protective measures has therefore been largely consistent. Assets susceptible to requests for protective measures have not been restricted by the Court to those with a link to the crimes(s) with which an accused person is charged. ${ }^{116}$ Further, where conflicting rights and interests have been identified, the Court has applied and interpreted the various safeguards included in the Rome Statute and RPE in a clear and transparent fashion, and, moreover, in fulfilment of its duty to do so in a manner that is 'consistent with internationally recognized human rights'.117

\section{Concluding remarks}

Pre-trial 'protective measures for the purpose of forfeiture' are not unique to ICTs. Their availability and use can be seen in the national legal systems of states with both common and civil law legal traditions, including in Senegal, as discussed above. ${ }^{118}$ But international criminal proceedings are not national criminal proceedings. Investigations and trials at the international level generally take much longer than domestic criminal cases. According to a 2013 study by Alette Smeulers, Barbora Hola and Tom van den Berg, the average length of time between the issuance of the indictment and trial judgment at nine international(ized) criminal tribunals was 4.9 years, while the average trial length was 2.9 years. ${ }^{119}$

\footnotetext{
${ }^{110}$ Ibid., at para. 18.

${ }^{111}$ Ibid., at para. 19.

${ }^{112} \mathrm{Ibid}$., at para. 20, citing ICC RPE, supra note 30, at Rule 21(5): 'Where a person claims to have insufficient means to pay for legal assistance and this is subsequently found not to be so, the Chamber dealing with the case at that time may make an order of contribution to recover the cost of providing counsel.'

${ }^{113}$ Ibid., at para. 22.

${ }^{114}$ Ibid., at para. 23.

${ }^{115}$ Ibid., at para. 22.

${ }^{116}$ On which see L. van den Herik, 'The Individualization of Enforcement in International Law: Exploring the Interplay between United Nations Targeted Sanctions and International Criminal Proceedings', in T. Maluwa, M. du Plessis and D. Tladi (eds.), The Pursuit of a Brave New World in International Law: Essays in Honour of John Dugard (2017), 234, at 260: 'Article 75(4) of the ICC Statute seems to indicate that protective measures solely for reparation purposes can only be made after conviction. Yet, in practice, Pre-Trial Chambers have effectively ordered the identification, tracing, freezing or seizing of assets already in the pre-trial phase with a view to rendering the reparation system effective. In case of a request for protective measures for reparation purposes, there is no requirement that the assets have a nexus with the crime.'

${ }^{117}$ Rome Statute, supra note 1, at Art. 21(3).

${ }^{118}$ See Senegalese Code of Criminal Procedure, supra note 6, at Art. 87bis.

${ }^{119}$ A. Smeulers, B. Hola and T. van den Berg, 'Sixty-Five Years of International Criminal Justice: The Facts and Figures', (2013) 13 IntlCLR 7, at 16-18. The study provides empirical data gathered from the IMT, the IMTFE, the ICTY, the ICTR, the ICC, the SCSL, the ECCC, the STL, and the Special Panels for Serious Crimes.
} 
This is not to say that international(ized) criminal trials take too long. Indeed, it has been argued that ICTs may be generally regarded as more 'efficient' given the complexity of the cases before them. ${ }^{120}$ But the time required for international criminal proceedings to reach completion can lead to problems with respect to assets frozen at the arrest warrant phase, an example of which can be seen in the case of Jean-Pierre Bemba Gombo. At the time of his arrest, unlike most other suspects apprehended by the Court as of the time of writing, Bemba had accumulated significant assets including a luxury private jet, as a result of his successful 'business empire'. ${ }^{121}$ As of March 2012, it was reported that this aircraft, which had already lost its flightworthiness, had accumulated more than $€ 126,000$ in parking fees at Faro Airport, which would likely surpass the value of the aircraft in the near future. ${ }^{122}$ On 8 June 2018, Bemba was acquitted of the charges brought against him by the Court's Prosecutor ${ }^{123}$ and his defence has subsequently requested that any freezing orders against his assets be lifted. ${ }^{124}$ If successful in this application, Bembas's aircraft will presumably be unfrozen and be of negative value as a result of the parking charges accumulated during his time in detention in The Hague, which, at the time of his acquittal, amounted to over ten years. It is therefore evident that the implications of decisions taken under Article 57(3)(e) of the Rome Statute and Rule 99 of the ICC RPE are potentially far-reaching.

The Rome Statute and ICC RPE include a series of due-process guarantees in respect of protective measures, the application of which can be clearly seen in the ICC's case law. Those most clearly affected are accused persons, the Prosecutor, potential victims, and bona fide third parties. The three factors to be considered by the pre-trial chamber under Article 57(3)(e) are: (i) the strength of the evidence; (ii) the rights of the parties concerned in the process; and (iii) the ultimate benefit of victims. Consequently, although not 'parties' to proceedings to the same extent as the Prosecutor and accused persons, victims' interests are given significant weight in the ICC legal framework as concerns protective measures. This is also borne out through an analysis of the Court's case law.

In discussing the most suitable approach to balancing the rights of accused persons with the rights of victims before the ICC, Zappalà expressed the following opinion:

it is often difficult to strike the proper balance between conflicting interests on a case-by-case basis. The case-by-case approach creates problems of consistency in the treatment of different defendants, which in turn threatens the principle of equality before the law. ${ }^{125}$

This article has sought to demonstrate that the Court has in its publicly available case law applied the safeguards in its legal framework with an even hand. From this jurisprudence, the parties to, and other participants concerned with, the protective measures process are able to seek largely consistent guidance with respect to ongoing (and future) proceedings pertaining to the protective identification, tracing, freezing and/or seizure of assets. Given the interests at stake, the Court's approach to protective measures is praiseworthy.

Author ORCID. Daley J. Birkett 0000-0002-2516-754X

\footnotetext{
${ }^{120}$ S. Ford, 'Complexity and Efficiency at International Criminal Courts', (2014) 29 EmoryIntlLRev 1.

${ }^{121}$ At the time of his first appearance before the ICC, Bemba is reported to have owned 'a large business empire' (M. Simons, 'Jean-Pierre Bemba, Congolese politician, appears in Hague court', New York Times, 4 July 2008).

${ }^{122}$ See B. Pires, 'Junk or worth preserving?', Jornal 123 Portugal, 14 March 2012.

${ }^{123}$ Prosecutor v. Bemba, Judgment on the appeal of Mr Jean-Pierre Bemba Gombo against Trial Chamber III's 'Judgment pursuant to Article 74 of the Statute', ICC-01/05-01/08-3636-Red, A.Ch., 8 June 2018.

${ }^{124}$ Prosecutor v. Bemba, Public Redacted Version of 'Preliminary application for reclassification of filings, disclosure, accounts and partial unfreezing of Mr. Bemba's assets', ICC-01/05-01/08-3654-Red, T.Ch. III, 30 October 2018.

${ }^{125}$ S Zappalà, 'The Rights of Victims v. the Rights of the Accused', (2010) 8 JICJ 137, at 142.

Cite this article: Birkett DJ (2019). Pre-trial 'Protective Measures for the Purpose of Forfeiture' at the International Criminal Court: Safeguarding and balancing competing rights and interests. Leiden Journal of International Law 32, 585-602. https:// doi.org/10.1017/S0922156519000153
} 